\title{
HEATS OF COMBUSTION OF ANTHRACITE COKES AND OF ARTIFICIAL AND NATURAL GRAPHITES ${ }^{1}$
}

\author{
By Phillip H. Dewey ${ }^{2}$ and D. Roberts Harper, $3 \mathrm{~d}^{3}$
}

\section{ABSTRACT}

There have been determined the heats of combustion of 30 samples of anthracite coke of known different temperatures of preparation $\left(900^{\circ}\right.$ to $\left.1,300^{\circ} \mathrm{C}\right)$, hydrogen contents (0.08 to 0.78 percent), and adsorptive capacities $\left(0.13\right.$ to $37.5 \mathrm{~cm}^{3}$ of gaseous $\mathrm{CO}_{2}$ per gram of solid carbon), in order to study the effect of these properties on the energy content of the material. Data were also obtained on the heats of combustion of two samples of pure ash-free artificial graphite and four different samples of natural graphite.

The heats evolved, expressed in international kilojoules, for the combustion of 1 mole of solid carbon to form $\mathrm{CO}_{2}$, at $25.0^{\circ} \mathrm{C}$ and a pressure of 1 atmosphere, without the production of external work, are as follows: Artificial graphite No. 0, $393.39 \pm 0.17$; artificial graphite No. $1,393.25 \pm 0.15$; Ticonderoga natural graphite, $393.32 \pm 0.11$; Buckingham natural graphite, $393.35 \pm 0.13$; Baffin Island natural graphite, $393.37 \pm 0.26$; and hydrogen-free anthracite coke, 403.03 \pm 0.29 (obtained by linear extrapolation to zero hydrogen content of the data on the hydrogen-containing cokes).

\section{CONTENTS}

I. Introduction

II. Material

III. Apparatus and method

IV. Calibration experiments

V. Combustion experiments on carbon

1. Anthracite cokes

2. Artificial and natural graphites

\section{INTRODUCTION}

The heats of combustion of samples of carbon from many different sources have been reported in the literature. The graphites used have been natural graphites $[1,2,3,4,5,6],{ }^{4}$ Acheson graphite $[2,5,6,7]$, and blast-furnace and pig-iron graphite $[2,8]$. The "amorphous" carbons have been wood charcoal [3, 8], and gas carbons $[1,4,6,7]$. The values reported range from 7,894 to $8,272 \mathrm{cal} / \mathrm{g}$ of carbon for "amorphous" carbon and from 7,842 to $7,932 \mathrm{cal} / \mathrm{g}$ of

\footnotetext{
1 In this and the following paper (RP1140) are presented the experimental results obtained in a cooperative investigation of the thermochemistry of carbon by the Coal Research Laboratory of the Carnegie Institute of Technology and by the National Bureau of Standards. The work described in this paper was performed at the former institution as part of the program of fundamental research on coal and derived products, under the direction of $\mathrm{H}$. H. Lowry.

${ }^{2}$ Formerly at the Coal Research Laboratory of the Carnegie Institute of Technology, now with the Pittsburg Plate Glass Co.

${ }^{3}$ Formerly at the Coal Research Laboratory of the Carnegie Institute of Technology, now deceased.

4 Figures in brackets throughout the text indicate the literature references at the end of this paper.
} 
carbon for graphite. The present work was undertaken to obtain accurate data on heats of combustion of several samples of artificial and natural graphites and of various specially prepared anthracite cokes containing known different amounts of hydrogen, and to study the effect of the following factors on the energy content of the anthracite cokes: Thermal history, hydrogen content, adsorptive capacity, activity, and porosity.

\section{MATERIAL}

The benzoic acid used to calibrate the calorimeter was Standard Sample 39e from the National Bureau of Standards. It was pressed into pellets and weighed in the crucible in which it was to be burned.

The carbons used in the study of the effect of chemical and physical properties were anthracite cokes prepared and analyzed at the Bell Telephone Laboratories according to the procedure outlined by $\mathrm{H}$. $\mathrm{H}$. Lowry [9] and under his supervision. The hydrogen content (\% of carbon $+\%$ of hydrogen $=100 \%$ ) ranged from 0.08 to 0.78 percent. The charge was weighed in the crucible in which it was to be burned, placed in a vacuum desiccator over calcium chloride, and evacuated for 4 hours with a Cenco Hyvac pump to a pressure less than $0.01 \mathrm{~mm}$ Hg. A liquid-air trap filled with activated charcoal was placed between the pump and desiccator to prevent the possibility of oil vapors backing up from the pump and being adsorbed by the sample. The necessity for this was shown by the fact that when there was no trap, the heat of combustion of the sample increased with time of evacuation, the increase being as much as $280 \mathrm{j} / \mathrm{g}$ of carbon. The vacuum was broken by admitting dry nitrogen through the second liquid-air trap connected between the desiccator and the activated charcoal trap. The sample was weighed again and immediately placed in the bomb.

The artificial graphite was spectroscopically pure graphite furnished by the National Carbon Co. in sticks $0.6 \mathrm{~cm}$ in diameter and $30 \mathrm{~cm}$ long, each piece wrapped in Cellophane. It is reported to have only 5 parts per million of impurities. Half of each stick was pulverized with an agate mortar and pestle to pass 150 -mesh platinum gauze. Care was taken that the graphite was not contaminated in any way by coming in contact with any organic material other than the Cellophane in which it was wrapped.

The four samples of natural graphite were obtained from Ward's Natural Science Establishment, Rochester, N. Y., and are designated by the location where found. The specimens ranged in size from approximately $100 \mathrm{~g}$ to $1 \mathrm{~kg}$, and all specimens consisted of welldefined crystals. In preparing the samples for combustion, approximately $20 \mathrm{~g}$ of the best crystals were cut out of the specimen, broken up in an agate mortar (all pieces of rock were thrown out), and ground for 36 hours in a porcelain mill with flint pebbles. Approximately 40 percent of the material passed a 150 -mesh screen, and the size distribution showed that the grinding was attrition rather than impact grinding. After sifting the graphite, the particles smaller than 150 mesh were sealed in an evacuating system consisting of a liquid-air trap and a Cenco Hyvac pump and evacuated for 6 hours at $225^{\circ} \mathrm{C}$.

The oxygen used was commercial atmospheric oxygen obtained in steel tanks at a pressure of 1,800 pounds. It was passed through a purifying train consisting of high-pressure bombs at room tempera- 
ture, containing silica gel, Hopcalite catalyst, palladized asbestos, Ascarite, and Anhydrone, to remove traces of combustible material, carbon dioxide, and moisture. This purifying train was tested from time to time to check its effectiveness. At no time could any combustible material or carbon dioxide be detected in the issuing oxygen.

\section{APPARATUS AND METHOD}

The bomb was a regular Parr illium bomb chamber with a specially built two-valve stainless-steel head patterned after that of the Kroeker-Peters bomb used by Dickinson [10]. The bomb capacity was $390 \mathrm{~cm}^{3}$. The gas inlet beyond the inlet valve was extended to within about $25 \mathrm{~mm}$ of the bottom of the bomb by means of a $2.5-\mathrm{mm}$ platinum tube. About $6 \mathrm{~mm}$ above the end of the tube was welded a platinum-ring crucible support. The tube served to introduce the oxygen below the crucible to prevent disturbing the charge. Approximately $13 \mathrm{~mm}$ above the ring a 1-mm platinum wire, which served as ground lead for the firing fuse, was welded to the tube. The other firing lead consisted of a $1.5-\mathrm{mm}$ platinum rod extending to within approximately $25 \mathrm{~mm}$ of the ring, terminating in about $25 \mathrm{~mm}$ of No. $22(0.64 \mathrm{~mm})$ platinum wire for manipulation. The fuse was a $9.0-\mathrm{mm}$ length of 0.15 -mm pure platinum wire

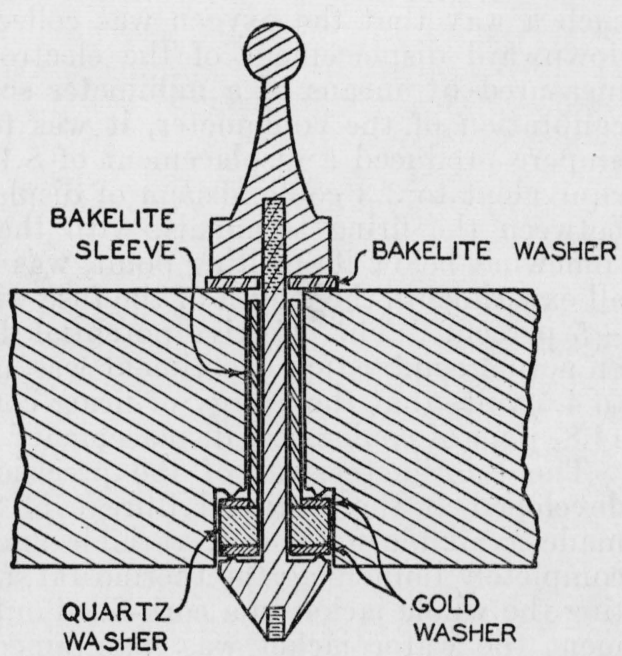

FIGURE 1.-Method of insulating the firing pin. and the charge of carbon was fired in every case without the addition of an auxiliary substance.

All oxidizable substances were eliminated from the interior of the bomb. The gasket between the bomb chamber and the head was pure gold, and the firing pin through the head was insulated from it by means of a quartz washer made tight with a pure gold gasket on either side. (See fig. 1.) The crucibles used with benzoic acid and the roasted anthracites were platinum and that used with the graphites was Vitreosil.

In order to obtain complete combustion of the roasted anthracites, a platinum crucible simulating a grate was used. The pure platinum crucible, $1 \mathrm{~mm}$ thick, had a rounded bottom, drilled with $0.5-\mathrm{mm}$ holes over the entire bottom and up the sides to within $3 \mathrm{~mm}$ of the top, with a spacing of approximately 450 holes per square inch. Into this was pressed a $38-\mathrm{mm}$ square of pure platinum 150-mesh gauze on which rested the 60 to 80 -mesh sample. In this way a supply of oxygen to each particle of carbon was assured, smothering of the flame by carbon dioxide and/or ash was prevented, and the 
necessity of the use of asbestos mats to obtain complete combustion was avoided, thereby eliminating indeterminate heats of reaction due to slagging of asbestos and mineral matter in the carbon samples.

When this arrangement was tried with the graphite samples, the electrical conductivity of the graphite caused such a leakage loss to the grounded platinum crucible that the firing-energy measurement was rendered valueless. It was found that if the graphite was powdered very finely, to pass through 150-mesh platinum gauze, and burned in a Vitreosil crucible, it could be ignited with 2 to $8 \mathrm{j}$ of firing energy, with practically complete combustion and with very little fusion of the ash with the Vitreosil.

The firing energy was obtained from an 18-volt lead storage battery. An oxygen coulometer, in series with the fuse wire, was arranged in such a way that the oxygen was collected in a narrow tube by the downward displacement of the electrolyte, the displacement being measured by means of a millimeter scale behind the tube. In the calibration of the coulometer, it was found that a current of 0.772 ampere produced a displacement of $8.18 \mathrm{~cm}$ in 35 seconds, which is equivalent to 3.3 coulombs/cm of displacement. The potential drop between the firing terminals, with the fuse wire at a temperature somewhat below its melting point, was measured to be 4.5 volts. In all experiments the length of the fuse wire was the same within about \pm 5 percent. The effective potential drop in the firing operation in an actual combustion experiment was assumed to be sufficiently near to 4.5 volts that the energy of firing could be taken as (3.3) (4.5) or $14.8_{5} \mathrm{j} / \mathrm{cm}$ of coulometer displacement. ${ }^{5}$

The calorimeter was of the precision type patterned after that developed at the National Bureau of Standards by Dickinson [10], made available for use at variable and high room temperatures by completely immersing the thermostat, adding a cooling coil, and putting the whole jacket in a cork-filled outer jacket. During an experiment the water jacket was maintained at a temperature of $25.00^{\circ}$ $\pm 0.01^{\circ} \mathrm{C}$.

The calorimeter temperature rise was measured by means of a Leeds \& Northrup calorimetric-type platinum-resistance thermometer used in conjunction with a Leeds \& Northrup resistance thermometer bridge (Mueller type) and a Weston galvanometer giving a deflection of about $1 \mathrm{~mm}$ for a resistance change of $0.0001 \mathrm{ohm}$. The initial and final temperatures were $23.70^{\circ} \mathrm{C}$ and approximately $25.9^{\circ} \mathrm{C}$, respectively. Since the temperature rise during the calibration experiments corresponded to within $\pm 0.15^{\circ} \mathrm{C}$ of that of the combustion experiments, the relation between the resistance of the thermometer and temperature is necessary only in determining the absolute temperature of the reaction and in checking the resistance for constancy. The fundamental interval was determined several times during the work with the results listed below:

${ }^{5}$ Accurately, the firing energy is the integral, over the time of firing, of $E I d t$, where $E$ and $I$ are the values of the voltage and current at a time $t$. The coulometer actually measures the integral of Idt over the time of firing, and, therefore, in the above procedure, the firing energy is only evaluated correctly if $E$ is constant. Examination of the data shows that in some experiments the firing energy was 20 or 30 times that in others. Since experiments where arcing inside the bomb was more than momentary, as evidenced by the reading of an ammeter in the firing circuit, were discarded at once, the difference in firing energy in the other experiments was most probably due to differences in the time required to start the reaction. If the firing current was insufficient to melt the fuse wire, the assumption that the effective value of $E$ was 4.5 volts appears reasonable. At any rate, the results of the experiments in which the calculated firing energy was large are not significantly different from those in which it was small, and the results are, therefore, not inconsistent with foregoing assumption as to the average effective value of $E$. 


\begin{tabular}{|c|c|c|}
\hline Date & $R_{0}$ (ohms) & $\begin{array}{c}R_{100}-R_{0} \\
\text { (ohms) }\end{array}$ \\
\hline $\begin{array}{l}10 / 22 / 34 \\
5 / 20 / 35 \\
12 / 2 / 35\end{array}$ & $\begin{array}{l}\text { 25. } 39795 \\
25.39803 \\
25.39801\end{array}$ & $\begin{array}{l}\text { 9. } 94315 \\
\text { 9. } 94328 \\
9.94356\end{array}$ \\
\hline
\end{tabular}

The mass of the sample was determined by direct weighing, and the weight of carbon dioxide formed in the combustion was determined by absorption in Ascarite and weighing [11]. This latter value was used to determine the amount of reaction and therefore was used in calculating the heats of combustion, since the carbons used contained various amounts of ash, unknown amounts of adsorbed moisture and gases, and known different amounts of hydrogen. The analytical train consisted of a modified U-tube containing lead peroxide distributed on asbestos fiber and maintained at a temperature of $218^{\circ} \mathrm{C}$ by boiling naphthalene, followed by a phosphorus pentoxide drying tube and three Ascarite U-tubes. On calibrating the lead peroxide tube, it was found that the tube increased in weight by 70 to 75 percent of the weight of nitric acid passed into it, the reaction corresponding to

$$
\mathrm{PbO}_{2}+2 \mathrm{HNO}_{3} \longrightarrow \mathrm{Pb}\left(\mathrm{NO}_{3}\right)_{2}+\mathrm{H}_{2} \mathrm{O}+1 / 2 \mathrm{O}_{2},
$$

wherein 73 percent of the weight of $\mathrm{HNO}_{3}$ is retained as $\mathrm{Pb}\left(\mathrm{NO}_{3}\right)_{2}$, since 1 mole of $\mathrm{H}_{2} \mathrm{O}$ and 0.5 mole of $\mathrm{O}_{2}$ are given off for each 2 moles of $\mathrm{HNO}_{3}$ taken up. The first Ascarite tube absorbed the carbon dioxide, the second served as a check tube, and the third was used as a counterpoise in weighing. The analytical train was followed by a flowmeter and a bubble tube containing palladium chloride to test for carbon monoxide. In only one case was any carbon monoxide found, although the test was determined to be sensitive to an absolute quantity of $0.05 \mathrm{~cm}^{3}$ of carbon monoxide. Determination of the carbon dioxide formed in the combustion of benzoic acid in the calibration runs was used to check the analytical train.

The energy equivalent of the calorimeter was determined by several combustions of benzoic acid and checked by a benzoic acid combustion after every specimen of roasted anthracite (three combustions) and graphite (four combustions). The calorimetric determinations were carried out essentially according to the procedure outlined by Dickinson[10].

No attempt was made to have exactly the same mass of water in the calorimeter, but a "standard" calorimeter was decided upon, and any deviation from this was determined and added as a correction to the energy equivalent as calculated to give a "standard" energy equivalent. In addition to the calorimeter can and thermometer, the "standard" calorimeter consisted of: Bomb, $3566.16 \mathrm{~g}$; water inside bomb, $1.00 \mathrm{~g}$; crucible, $4.84 \mathrm{~g}$; charge, $1.16 \mathrm{~g}$ of benzoic acid; oxygen, $14.50 \mathrm{~g}$; and water, $2872.00 \mathrm{~g}$. The weight of water was not allowed to vary from $2,872 \mathrm{~g}$ by more than 0.5 percent (with one or two exceptions) and the difference in weight of any of these quantities was determined to the nearest $0.01 \mathrm{~g}$, all weighed in air against brass weights. This difference times the energy equivalent of the substance per ohm change of resistance of the thermometer gives the correction to the determined energy equivalent.

One gram of water was placed in the bomb to saturate the space with water vapor at the beginning of the experiment. The air initially in the bomb was flushed out by filling with oxygen to 50 atmos- 
pheres and then releasing to atmospheric pressure. The bomb was then filled to 30 atmospheres and allowed to stand, to a depth of several centimeters, in water at about $60^{\circ} \mathrm{C}$ for 1 minute to make sure the space within the bomb was completely saturated with water vapor.

The observed temperature rise was corrected for heat transfer between calorimeter and jacket, and heat of stirring by Dickinson's method [10]. After the calorimetric determinations, the bomb was placed in a water bath and, by means of a high-pressure stainless-steel connection and a steel-to-glass ground joint, slowly discharged through the analytical train. During the discharge, which required approximately $1 \frac{1}{2}$ hours, the water bath was warmed to approximately $60^{\circ} \mathrm{C}$, and after the pressure had reached atmospheric pressure, the bomb was flushed with oxygen (free of carbon dioxide and water) for 2 hours. This left the bomb flushed free of all carbon dioxide, water, and nitric acid. The naphthalene bath was removed from the lead peroxide tube and the tube allowed to cool with the oxygen still flowing, after which the tubes were wiped and weighed, closed to the atmosphere. The lead peroxide tube was closed by means of cork stoppers which were removed during weighing.

\section{CALIBRATION EXPERIMENTS}

The energy equivalent of the calorimeter is given by

$$
K_{t_{m}}=\frac{A_{t_{n}} \cdot a+14.85 d+1315 c}{t_{n}-t_{0}},
$$

where $K_{t_{m}}$ is the energy equivalent of the calorimeter in joules per unit rise of temperature, at the mean temperature; $A_{t_{n}}$ is the heat of combustion per gram mass of benzoic acid at the final temperature, and $a$ is the mass of sample in grams; $d$ is the difference in centimeters in the coulometer readings before and after firing, and the constant $14.85 \mathrm{j} / \mathrm{cm}$ serves as a multiplier to give the firing energy in joules; $c$ is the increase in weight of the lead peroxide tube in grams and the constant $1,315 \mathrm{j} / \mathrm{g}$ serves as a multiplier to give the correction for the formation of nitric acid; and $t_{n}-t_{0}$ is the corrected temperature rise or increase in resistance of the thermometer in ohms. The heat of formation of aqueous nitric acid, according to the reaction, $1 / 2 \mathrm{H}_{2} \mathrm{O}$ (liq) $+1 / 2 \quad \mathrm{~N}_{2}(\mathrm{~g})+5 / 4 \mathrm{O}_{2}(\mathrm{~g})=\mathrm{HNO}_{3}(\mathrm{aq}, 0.005 \mathrm{M})$, is taken as $-\Delta U=60.5 \mathrm{kj} / \mathrm{mole}$.

In table 2 are given the results of 42 calibration combustions, using 26,418 NBS int. $\mathrm{j} / \mathrm{g}$ (mass) as the value for the heat evolved on the combustion of benzoic acid at $25.9^{\circ} \mathrm{C}$, the final temperature, under the standard conditions of the bomb process, that is, when the initial oxygen pressure is 30 atmospheres and the masses of benzoic acid and water placed in the bomb are $3 \mathrm{~g} /$ liter of bomb volume [12]. This mass of benzoic acid under these conditions gives a "temperature" rise of $0.220 \mathrm{ohm}$ for the "standard" calorimeter.

The energy equivalent of the calorimeter is expressed in international joules per ohm increase in resistance of the given platinum resistance thermometer at the given mean temperature of the experiments, and the calorimeter is thus used merely as a comparator between benzoic acid and carbon [14]. The amount of reaction in the calibration experiments was determined from the mass of benzoic acid burned. The sample was weighed in air against brass weights. Data and calculations for a typical calibration combustion are given in table 1. 
TABLE 1.-Data sheet for the combustion of benzoic acid, National Bureau of Standards Sample $39 e$

Experiment 76-29.

[Jacket temperature $25.00^{\circ} \mathrm{C}$ ]

Date $9 / 16 / 35$

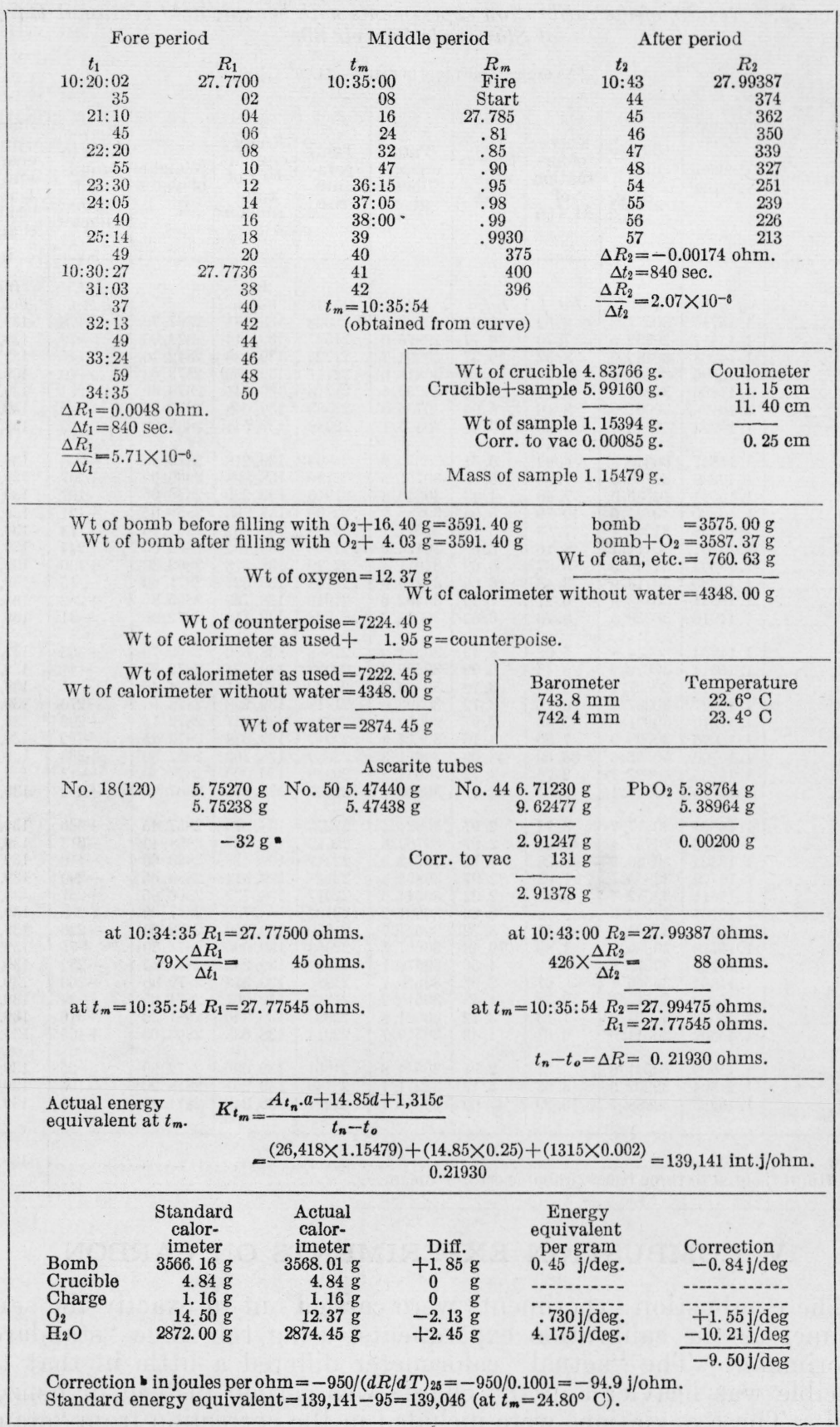

- Change in weight of counterpoise due to change of buoyancy of air.

- $\delta$ for this thermometer was taken as 1.48 , which gives $(d R / d T)_{25}=0.1001 \mathrm{ohm} / \mathrm{deg}$. 
The data for the anthracite cokes and the graphites were worked up in the same manner.

TABLE 2.-Results of the calibration experiments with benzoic acid National Bureau of Standards Sample $39 e$

[Average mean temperature, $24.80^{\circ} \mathrm{C}$ ]

\begin{tabular}{|c|c|c|c|c|c|c|c|c|c|c|}
\hline Experiment & $\begin{array}{l}\text { Mass of } \\
\text { sample }\end{array}$ & $\begin{array}{l}\text { Energy } \\
\text { liber- } \\
\text { ated by } \\
\text { sample }\end{array}$ & $\begin{array}{c}\text { Energy } \\
\text { of for- } \\
\text { mation } \\
\text { of } \\
\mathrm{HNO}_{3}\end{array}$ & $\begin{array}{c}\text { Energy } \\
\text { of fir- } \\
\text { ing }\end{array}$ & $\begin{array}{c}\text { Total } \\
\text { energy } \\
\text { liber- } \\
\text { ated }\end{array}$ & $\begin{array}{l}\text { Tem- } \\
\text { pera- } \\
\text { ture } \\
\text { rise }\end{array}$ & $\begin{array}{l}\text { Energy } \\
\text { equiva- } \\
\text { lent of } \\
\text { calo- } \\
\text { rimeter }\end{array}$ & $\begin{array}{l}\text { Weight } \\
\text { of water }\end{array}$ & $\begin{array}{l}\text { Correc- } \\
\text { tion to } \\
\text { stand- } \\
\text { ard } \\
\text { calo- } \\
\text { rimeter }\end{array}$ & $\begin{array}{l}\text { Stand- } \\
\text { ard } \\
\text { energy } \\
\text { equiva- } \\
\text { lent of } \\
\text { calo- } \\
\text { rimeter }\end{array}$ \\
\hline $\begin{array}{l}57-51 \\
57-65 \\
57-79 \\
57-81 \\
57-87 \\
57-91 \\
57-99\end{array}$ & $\begin{array}{c}g \\
1.15744 \\
1.13417 \\
1.14263 \\
1.16596 \\
1.14496 \\
1.16178 \\
1.15993\end{array}$ & $\begin{array}{c}\text { Int. } j \\
\text { 30577. } \\
29962.5 \\
30186.0 \\
30802.3 \\
30247.6 \\
30691.9 \\
30643.0\end{array}$ & $\begin{array}{r}\text { Int. } j \\
9.62 \\
7.70 \\
8.37 \\
10.54 \\
6.61 \\
8.16 \\
5.65\end{array}$ & $\begin{array}{r}\text { Int. } j \\
5.94 \\
4.77 \\
10.37 \\
5.19 \\
5.19 \\
5.94 \\
6.40\end{array}$ & $\begin{array}{c}\text { Int. }{ }^{j} \\
30592.8 \\
29975.0 \\
30204.7 \\
30818.0 \\
30259.4 \\
30706.0 \\
30655.1\end{array}$ & $\begin{array}{r}\text { Ohms } \\
0.22028 \\
.21547 \\
.21724 \\
.22147 \\
.21716 \\
.22083 \\
.22288\end{array}$ & $\begin{array}{c}\text { Int. } \\
\text { j/ohm } \\
138,881 \\
139,114 \\
139,038 \\
139,152 \\
139,341 \\
139,048 \\
137,541\end{array}$ & $\begin{array}{c}g \\
2867.70 \\
2874.00 \\
2872.10 \\
2873.62 \\
2878.69 \\
2872.25 \\
2838.00\end{array}$ & $\begin{array}{c}\text { Int. } \\
\text { j/ohm } \\
+178 \\
-79 \\
-5 \\
-70 \\
-274 \\
-5 \\
+1,392\end{array}$ & $\begin{array}{c}\text { Int. } \\
\text { j/ohm } \\
139,059 \\
139,035 \\
139,033 \\
139,082 \\
139,067 \\
139,043 \\
138,933\end{array}$ \\
\hline $\begin{array}{l}69-9 \\
69-25 \\
69-33 \\
69-47 \\
69-55 \\
69-63- \\
69-73 \ldots \\
69-81 \ldots \\
69-91 \ldots \\
69-99\end{array}$ & $\begin{array}{l}1.14847 \\
1.16239 \\
1.15584 \\
1.16290 \\
1.19458 \\
1.13991 \\
1.19609 \\
1.16265 \\
1.15031 \\
1.14916\end{array}$ & $\begin{array}{l}30340.3 \\
30708.0 \\
30535.0 \\
30721.5 \\
31558.4 \\
30114.1 \\
31598.3 \\
30714.9 \\
30388.9 \\
30358.5\end{array}$ & $\begin{array}{r}6.69 \\
7.86 \\
7.40 \\
10.79 \\
7.53 \\
8.16 \\
6.07 \\
3.43 \\
6.27 \\
8.70\end{array}$ & $\begin{array}{r}6.61 \\
35.68 \\
4.43 \\
5.94 \\
5.19 \\
6.65 \\
6.69 \\
6.69 \\
7.40 \\
6.53\end{array}$ & $\begin{array}{l}30353.6 \\
30751.5 \\
30546.8 \\
30738.2 \\
31571.1 \\
30128.9 \\
31611.1 \\
30725.0 \\
30402.6 \\
30373.7\end{array}$ & $\begin{array}{l}.21803 \\
.22146 \\
.21940 \\
.22130 \\
.22729 \\
.21708 \\
.22779 \\
.22100 \\
.21916 \\
.21834\end{array}$ & $\begin{array}{l}139,218 \\
138,898 \\
139,229 \\
138,898 \\
138,902 \\
138,792 \\
138,773 \\
139,027 \\
138,723 \\
139,112\end{array}$ & $\begin{array}{l}2876.80 \\
2866.90 \\
2876.95 \\
2869.05 \\
2867.70 \\
2866.05 \\
2862.30 \\
2871.60 \\
2865.85 \\
2872.85\end{array}$ & $\begin{array}{r}-200 \\
+207 \\
-207 \\
+121 \\
+173 \\
+244 \\
+400 \\
+15 \\
+252 \\
-31\end{array}$ & $\begin{array}{l}139,018 \\
139,065 \\
139,022 \\
139,019 \\
139,075 \\
139,036 \\
139,173 \\
139,042 \\
138,975 \\
139,081\end{array}$ \\
\hline $\begin{array}{l}76-11 \\
76-29= \\
76-43= \\
76-53= \\
76-61= \\
76-87= \\
76-89- \\
76-91_{--}\end{array}$ & $\begin{array}{l}1.14864 \\
1.15914 \\
1.15479 \\
1.15027 \\
1.17310 \\
1.15826 \\
1.15700 \\
1.15935 \\
1.16720\end{array}$ & $\begin{array}{l}30344.8 \\
30622.2 \\
30507.2 \\
30387.8 \\
30991.0 \\
30598.9 \\
30565.6 \\
30627.7 \\
30835.1\end{array}$ & $\begin{array}{r}5.02 \\
3.43 \\
2.64 \\
0.46 \\
5.86 \\
7.20 \\
36.69 \\
2.76 \\
2.64\end{array}$ & $\begin{array}{r}4.43 \\
6.99 \\
3.72 \\
3.72 \\
2.97 \\
8.16 \\
48.99 \\
3.72 \\
2.97\end{array}$ & $\begin{array}{l}30354.2 \\
30632.6 \\
30513.6 \\
30392.0 \\
30999.8 \\
30614.3 \\
30651.3 \\
30634.2 \\
30840.7\end{array}$ & $\begin{array}{l}.21888 \\
.22023 \\
.21930 \\
.21818 \\
.22248 \\
.22017 \\
.22089 \\
.22039 \\
.22207\end{array}$ & $\begin{array}{l}138,680 \\
139,094 \\
139,141 \\
139,298 \\
139,337 \\
139,048 \\
138,763 \\
139,000 \\
138,878\end{array}$ & $\begin{array}{l}2862.70 \\
2872.85 \\
2874.45 \\
2878.50 \\
2879.15 \\
2873.25 \\
2867.30 \\
2873.30 \\
2867.95\end{array}$ & $\begin{array}{r}+363 \\
-41 \\
-95 \\
-270 \\
-296 \\
+12 \\
+260 \\
+13 \\
+233\end{array}$ & $\begin{array}{l}139,043 \\
139,053 \\
139,046 \\
139,028 \\
139,041 \\
139,060 \\
139,023 \\
139,013 \\
139,111\end{array}$ \\
\hline $\begin{array}{l}81-61 \\
81-69 \\
81-77 \\
81-85 \\
81-93\end{array}$ & $\begin{array}{l}1.16654 \\
1.16426 \\
1.16324 \\
1.16779 \\
1.15611 \\
1.16167 \\
1.15843 \\
1.15778 \\
1.15727 \\
1.15664 \\
1.15499 \\
1.16046 \\
1.15507\end{array}$ & $\begin{array}{l}30817.7 \\
30757.4 \\
30730.5 \\
30850.7 \\
30542.1 \\
30689.0 \\
30603.4 \\
30586.2 \\
30572.8 \\
30556.1 \\
30512.5 \\
30657.0 \\
30514.6\end{array}$ & $\begin{array}{r}.54 \\
1.80 \\
0.71 \\
.67 \\
2.76 \\
1.13 \\
0.63\end{array}$ & $\begin{array}{r}2.97 \\
2.97 \\
3.72 \\
2.97 \\
2.22 \\
2.22 \\
3.72 \\
79.48 \\
4.56 \\
2.97 \\
4.43 \\
3.72 \\
4.43\end{array}$ & $\begin{array}{l}30824.4 \\
30760.6 \\
30742.5 \\
30855.3 \\
30544.6 \\
30691.2 \\
30607.7 \\
30667.5 \\
30578.1 \\
30559.7 \\
30519.7 \\
30661.8 \\
30519.7\end{array}$ & $\begin{array}{l}.22276 \\
.22029 \\
.22049 \\
.22148 \\
.22017 \\
.22122 \\
.21979 \\
.22063 \\
.21954 \\
.21936 \\
.21946 \\
.22004 \\
.22014\end{array}$ & $\begin{array}{l}138,375 \\
139,637 \\
139,428 \\
139,314 \\
138,732 \\
138,736 \\
139,259 \\
139,000 \\
139,282 \\
139,313 \\
139,067 \\
139,346 \\
138,638\end{array}$ & $\begin{array}{l}2857.45 \\
2888.40 \\
2883.60 \\
2880.65 \\
2866.95 \\
2867.00 \\
2879.00 \\
2871.70 \\
2879.65 \\
2879.80 \\
2874.05 \\
2881.20 \\
2863.60\end{array}$ & $\begin{array}{l}+666 \\
-613 \\
-416 \\
-290 \\
+267 \\
+268 \\
-226 \\
+75 \\
-252 \\
-260 \\
-24 \\
-316 \\
+405\end{array}$ & $\begin{array}{l}139,041 \\
139,024 \\
139,012 \\
139,024 \\
138,999 \\
139,004 \\
139,033 \\
139,075 \\
139,030 \\
139,053 \\
139,043 \\
139,030 \\
139,043\end{array}$ \\
\hline $\begin{array}{l}87-3 \ldots \ldots \\
87-13+\ldots-\ldots \\
87-21\end{array}$ & $\begin{array}{l}1.15609 \\
1.21894 \\
1.16923\end{array}$ & $\begin{array}{l}30541.6 \\
32202.0 \\
30888.7\end{array}$ & $\begin{array}{r}.21 \\
3.93 \\
10.29\end{array}$ & $\begin{array}{r}2.97 \\
5.19 \\
47.69\end{array}$ & $\begin{array}{l}30544.8 \\
32211.1 \\
30946.7\end{array}$ & $\begin{array}{l}.21961 \\
.23140 \\
.22257\end{array}$ & $\begin{array}{l}139,086 \\
139,201 \\
139,042\end{array}$ & $\begin{array}{l}2872.90 \\
2878.20 \\
2871.45\end{array}$ & $\begin{array}{r}+25 \\
-196 \\
+60\end{array}$ & $\begin{array}{l}139,111 \\
139,005 \\
139,102\end{array}$ \\
\hline \multicolumn{10}{|l|}{ Mean } & $\begin{array}{r}139,043 \\
12\end{array}$ \\
\hline
\end{tabular}

\section{COMBUSTION EXPERIMENTS ON CARBON}

The combustion experiments were carried out in exactly the same manner as the calibration experiments, using the same "standard" calorimeter. The "actual" calorimeter differed a little in that the crucible was heavier and the charge was carbon instead of benzoic acid. These deviations were included in the correction from "standard" energy equivalent to "actual" energy equivalent. The "stand- 
ard" energy equivalent used was the average of the 42 calibration experiments. After the first combustion of each sample, the mass of charge was adjusted to give the "standard" temperature rise, namely, $0.220 \mathrm{ohm}$.

The amount of reaction was determined from the mass of carbon dioxide formed in the combustion. This takes care of the presence of inert material in the sample and measures directly the amount of carbon burned. ${ }^{6}$ The degree of precision of the analysis was checked in the calibration experiments by determining the amount of carbon dioxide formed in exactly the same way as in the combustion experiments on the carbons. The ratio of " $\mathrm{CO}_{2}$ obtained" to "theoretical $\mathrm{CO}_{2}$ " from benzoic acid, using the atomic weights $\mathrm{C}=12.010, \mathrm{H}=$ 1.0078 , and $\mathrm{O}=16.0000$, is given in table 3 .

TABLE 3.-Analytical data on benzoic acid

\begin{tabular}{|c|c|c|c|c|c|}
\hline Experiment & $\begin{array}{l}\text { Theoret- } \\
\text { ical mass } \\
\text { of } \mathrm{CO}_{2}\end{array}$ & $\begin{array}{c}\text { Ratio: } \\
\text { Determined } \mathrm{CO}_{2} \\
\text { Theoretical } \mathrm{CO}_{2}\end{array}$ & Experiment & $\begin{array}{l}\text { Theoret- } \\
\text { ical mass } \\
\text { of } \mathrm{CO}_{2}\end{array}$ & $\begin{array}{c}\text { Ratio: } \\
\text { Determined } \mathrm{CO}_{2} \\
\text { Theoretical } \mathrm{CO}_{2}\end{array}$ \\
\hline $57-51$ & $\stackrel{g}{91993}$ & 100046 & 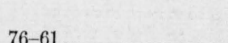 & $\stackrel{g}{g}$ & 100033 \\
\hline $57-65$ & $\begin{array}{l}2.81990 \\
2.86123\end{array}$ & $\begin{array}{l}\text { 1. } 00040 \\
\text { 0. } 99991\end{array}$ & $76-87$ & $\begin{array}{l}\text { 2. } 92200 \\
\text { 2. } 91882\end{array}$ & $\begin{array}{l}1.00033 \\
1.00047\end{array}$ \\
\hline $57-79$ & 2.88257 & 1. 00017 & $76-89$ & 2. 92475 & 1. 00053 \\
\hline $57-81 \ldots \ldots$ & 2. 94142 & 1. 00036 & & & \\
\hline $57-87 \ldots$ & 2.88845 & 0.99999 & $\begin{array}{l}76-91 \\
81-3\end{array}$ & $\begin{array}{l}2.94455 \\
2.94289\end{array}$ & $\begin{array}{l}1.00013 \\
1.00046\end{array}$ \\
\hline $57-91$ & 2. 93088 & 1. 00003 & $81-11$ & 2. 93714 & 1. 00066 \\
\hline $57-99$ & 2. 92621 & 1. 00048 & $81-15 \ldots$ & 2. 93456 & 1. 00016 \\
\hline $69-9=\ldots-25$ & 2. 89730 & 1.00007 & $81-19$ & 2. 94604 & 1.00029 \\
\hline $\begin{array}{l}69-25 \\
69-33\end{array}$ & $\begin{array}{l}2.93242 \\
2.91589\end{array}$ & $\begin{array}{l}1.00039 \\
1.00049\end{array}$ & 81-27. & 2. 91657 & 1. 00040 \\
\hline & & & $81-35$ & 2. 93060 & 1. 00063 \\
\hline $69-47 \ldots$ & 2. 93370 & 1.00025 & $81-43 \ldots$ & 2. 92243 & 1. 00037 \\
\hline $69-55$ & 3. 01363 & 0. 99985 & $81-53 \ldots$ & 292079 & 1. 00053 \\
\hline $\begin{array}{l}69-63 \\
69-73\end{array}$ & $\begin{array}{l}2.87571 \\
\text { 3. } 01743\end{array}$ & $\begin{array}{l}1.00031 \\
0.99980\end{array}$ & $81-61 \ldots$ & 2. 91950 & 1. 00045 \\
\hline 31 . & 2.93307 & 1. 00043 & $81-69 \ldots$ & 2. 91791 & 1. 00030 \\
\hline $69-91 \ldots$ & 2. 90194 & 1. 00038 & $81-85$ & $\begin{array}{l}2.91315 \\
2.92755\end{array}$ & 1. 00056 \\
\hline $69-99$ & 2. 89904 & 1. 00021 & $81-93 \ldots$ & 2. 91395 & 1. 00049 \\
\hline $76-9$ & 2. 89773 & 1. 00022 & $87-3$ & 2. 91652 & 0.99992 \\
\hline & 2. 92422 & 1. 00038 & & & \\
\hline $76-29$ & 2. 91324 & 1. 00019 & $87-13 \ldots \ldots \ldots$ & 3. 07508 & 1. 00040 \\
\hline \multirow{2}{*}{$76-43$} & \multirow{2}{*}{$\begin{array}{l}2.90184 \\
2.95944\end{array}$} & \multirow{2}{*}{$\begin{array}{l}\text { 1. } 00048 \\
\text { 1. } 00009\end{array}$} & \multirow{2}{*}{ Average....... } & 2.94967 & 1.00007 \\
\hline & & & & & 1. 00029 \\
\hline
\end{tabular}

\section{ANTHRACITE COKES}

In table 4 are given the heats of combustion of 30 samples of anthracite coke on each of which three combustions were made. These cokes were prepared at six different temperatures, ranging from $900^{\circ}$ to $1,300^{\circ} \mathrm{C}$, thereby giving cokes with six different hydrogen contents, since the hydrogen content of a given sample of coke depends on the thermal treatment to which it has been subjected [9]. The adsorptive capacity, $x / m$, in cubic centimeters of carbon dioxide absorbed per gram of carbon at $0^{\circ} \mathrm{C}$ and $760 \mathrm{~mm} \mathrm{Hg}$, and porosity, $P$, in cubic millimeters per gram, from which the activity, $A$, equal to $(x / m) / P$ is calculated, had been determined for each sample at the Bell Telephone Laboratories [13]. The details of these measurements may be found in the work referred to.

\footnotetext{
${ }^{6}$ Except when the sample contains carbonate. See, for example, p. 482, of the following paper.
} 
TABLE 4.- Heats of combustion of anthracite cokes

[Average mean temperature, $24.80^{\circ} \mathrm{C}$ ]

\begin{tabular}{|c|c|c|c|c|c|c|c|c|c|c|c|c|c|c|c|}
\hline Experiment & $\underset{\text { ple }}{\text { Sam- }}$ & $x / m$ & $P$ & $A$ & $\begin{array}{l}\text { Mass } \\
\text { before } \\
\text { evacua. } \\
\text { tion }\end{array}$ & $\begin{array}{l}\text { Mass of } \\
\text { carbon } \\
\text { dioxide } \\
\text { formed }\end{array}$ & $\begin{array}{c}\text { Tem- } \\
\text { perature } \\
\text { rise }\end{array}$ & $\begin{array}{l}\text { Weight } \\
\text { of water }\end{array}$ & $\begin{array}{c}\text { Deviation } \\
\text { from } \\
\text { standard } \\
\text { energy } \\
\text { equiva- } \\
\text { lent }\end{array}$ & $\begin{array}{l}\text { Energy } \\
\text { equiva- } \\
\text { lent of } \\
\text { calori- } \\
\text { meter }\end{array}$ & $\begin{array}{l}\text { Energy } \\
\text { of for- } \\
\text { mation } \\
\text { of } \\
\mathrm{HNO}_{3}\end{array}$ & \begin{tabular}{|c|} 
Energy \\
of \\
firing
\end{tabular} & $\begin{array}{c}\text { Heat of } \\
\text { combus- } \\
\text { tion un- } \\
\text { der condi- } \\
\text { tions of } \\
\text { bomb } \\
\text { process } 1\end{array}$ & \multicolumn{2}{|c|}{ A verage 2} \\
\hline \multicolumn{16}{|c|}{ TEMPERATURE OF PREPARATION $900^{\circ} \mathrm{C}$; HYDROGEN CONTENT 0.78 PERCENT } \\
\hline $\begin{array}{l}76-3-50 \\
76-7-79 \\
81-790 \\
81-811-23 \\
81-83\end{array}$ & 147 & $\begin{array}{l}\mathrm{cm}^{3} / g \\
34.58 \\
37.22\end{array}$ & $\begin{array}{r}m m^{3} / g \\
71.5\end{array}$ & $\begin{array}{r}c m^{3} / m m^{2} \\
0.482 \\
.460 \\
.446\end{array}$ & $\left\{\begin{array}{l}g \\
0.93756 \\
1.00195 \\
1.00109 \\
1.0002 \\
1.0119 \\
1.0213 \\
0.96464 \\
1.00122 \\
1.00221 \\
\end{array}\right.$ & $\begin{array}{l}g \\
\text { 3. } 03869 \\
\text { 3. } 24933 \\
\text { 3. } 24770 \\
3.22775 \\
\text { 3. } 17496 \\
3.29970 \\
\text { 3. } 13263 \\
\text { 3. } 22707 \\
\text { 3. } 23701 \\
\end{array}$ & $\begin{array}{c}\text { Ohms } \\
0.20643 \\
.22071 \\
.22155 \\
.21909 \\
.21512 \\
.22382 \\
.21215 \\
.21920 \\
.21951 \\
\end{array}$ & $\begin{array}{c}g \\
2872.95 \\
2873.90 \\
2870.20 \\
2872.50 \\
2877.35 \\
2873.70 \\
2879.75 \\
2872.20 \\
2870.25 \\
\end{array}$ & $\begin{array}{r}\text { Int.j/ohm } \\
-106.3 \\
-54.8 \\
-216.7 \\
-103.3 \\
+88.3 \\
-50.2 \\
+152.3 \\
-160.2 \\
-257.7 \\
\end{array}$ & $\begin{array}{r}\text { Int. } j / 0 h m \\
138,937 \\
138,988 \\
138,826 \\
138,940 \\
139,131 \\
138,993 \\
139,195 \\
138,883 \\
138,785 \\
\end{array}$ & $\begin{array}{r}\text { Int. } . \\
9.5 \\
13.0 \\
14.2 \\
14.8 \\
17.7 \\
22.5 \\
9.1 \\
11.7 \\
7.9 \\
\end{array}$ & $\begin{array}{r}\text { Int.j } \\
17.8 \\
20.8 \\
124.7 \\
4.8 \\
8.9 \\
48.9 \\
57.9 \\
63.8 \\
3.0 \\
\end{array}$ & \begin{tabular}{|r|} 
Int.j/g of C \\
34,554 \\
34,557 \\
34,547 \\
34,536 \\
34,513 \\
34,469 \\
34,465 \\
34,484 \\
34,475 \\
\end{tabular} & $\left\{\begin{array}{l}\text { Int. } j / g \text { of } \mathrm{C} \\
34,553 \\
34,506 \\
34,475\end{array}\right.$ & $\begin{array}{l}\text { callg of C } \\
8259.7 \\
8248.5 \\
8241.1\end{array}$ \\
\hline Group average ${ }^{3}-\ldots \ldots \ldots$ & $\cdots$ & $\mid-\ldots-1$ & $\mid-\ldots . . . .$. & 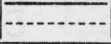 & & & 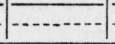 & & & 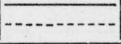 & & & $-\ldots$ & $\mid 34,511 \pm 26$ & $8249.8 \pm 6.3$ \\
\hline \multicolumn{16}{|c|}{ TEMPERATURE OF PREPARATION $1,000^{\circ} \mathrm{C}$; HYDROGEN CONTENT 0.49 PERCENT } \\
\hline $\begin{array}{l}69-37 \\
69-49 \\
69-45 \\
69-49 \\
69-67 \\
69-69 \\
69 \\
\text { Group average }\end{array}$ & 113 & $\begin{array}{l}22.58 \\
27.00 \\
32.05\end{array}$ & 57.3 & $\begin{array}{l}.473 \\
.387\end{array}$ & $\left\{\begin{array}{l}0.9997 \\
1.0015 \\
1.0031 \\
1.0208 \\
0.9903 \\
.9954 \\
1.00082 \\
1.01068 \\
1.00940 \\
1.0012 \\
1.0059 \\
1.0052 \\
0.94615 \\
1.00955 \\
1.01137 \\
1.00115 \\
1.04118 \\
1.04098 \\
1.0213 \\
1.0263 \\
0.9752 \\
-2 .-1\end{array}\right.$ & \begin{tabular}{|}
3.24567 \\
3.24122 \\
3.24662 \\
3.35356 \\
3.24874 \\
3.26788 \\
3.25566 \\
3.28339 \\
3.27895 \\
3.26678 \\
3.27356 \\
3.2787 \\
3.07049 \\
3.28069 \\
3.28769 \\
3.15279 \\
3.28380 \\
3.27745 \\
3.26875 \\
3.28549 \\
3.12801 \\
..- \\
..--
\end{tabular} & $\begin{array}{r}0.21743 \\
.21607 \\
.21741 \\
.22532 \\
.21815 \\
.21913 \\
.21808 \\
.22031 \\
.22038 \\
.22005 \\
.21965 \\
.22025 \\
.20564 \\
.22001 \\
.21889 \\
.21201 \\
.21989 \\
.21965 \\
.21923 \\
.22011 \\
.20953 \\
. . .-. .-\end{array}$ & \begin{tabular}{|l|}
2881.80 \\
2891.25 \\
2877.10 \\
2872.30 \\
2873.25 \\
2882.50 \\
2883.90 \\
2874.05 \\
2870.10 \\
2872.10 \\
2881.15 \\
2879.10 \\
2882.00 \\
2871.15 \\
2899.70 \\
2862.40 \\
2874.90 \\
2875.55 \\
2873.80 \\
2868.55 \\
2875.75 \\
\end{tabular} & \begin{tabular}{|r|}
+278.6 \\
+688.2 \\
+80.7 \\
-119.2 \\
-67.4 \\
+310.0 \\
+380.3 \\
-46.0 \\
-213.8 \\
-130.1 \\
+263.5 \\
+166.1 \\
+328.8 \\
-170.7 \\
+1031.2 \\
-538.0 \\
-12.5 \\
+15.5 \\
-56.1 \\
-277.8 \\
+36.4 \\
\end{tabular} & \begin{tabular}{|l|}
139,322 \\
139,731 \\
139,124 \\
138,924 \\
138,976 \\
139,353 \\
139,423 \\
138,997 \\
138,829 \\
138,913 \\
139,307 \\
139,209 \\
139,372 \\
138,872 \\
140,074 \\
138,505 \\
139,031 \\
139,059 \\
138,987 \\
138,765 \\
139,079 \\
\end{tabular} & \begin{tabular}{|r|}
20.2 \\
17.0 \\
16.0 \\
14.0 \\
16.3 \\
16.2 \\
18.2 \\
15.9 \\
11.8 \\
16.6 \\
17.2 \\
14.8 \\
19.5 \\
13.8 \\
19.8 \\
23.4 \\
17.7 \\
24.8 \\
16.1 \\
14.3 \\
21.8 \\
..--- \\
.--2
\end{tabular} & \begin{tabular}{|r|}
82.4 \\
15.9 \\
17.1 \\
77.1 \\
86.1 \\
94.2 \\
54.2 \\
16.8 \\
28.2 \\
69.8 \\
109.9 \\
90.4 \\
85.0 \\
14.1 \\
59.4 \\
102.9 \\
88.4 \\
96.6 \\
101.8 \\
14.1 \\
103.3 \\
...--
\end{tabular} & \begin{tabular}{|r|}
34,085 \\
34,096 \\
34,102 \\
34,105 \\
34,081 \\
34,118 \\
34,142 \\
34,140 \\
34,147 \\
34,192 \\
34,110 \\
34,156 \\
34,080 \\
34,096 \\
34,086 \\
33,983 \\
33,997 \\
34,015 \\
34,026 \\
34,035 \\
33,992 \\
\end{tabular} & $\left\{\begin{array}{l}33,998 \\
34,018\end{array}\right.$ & $\begin{array}{l}8150.0 \\
8151.7 \\
8161.7\end{array}$ \\
\hline
\end{tabular}


TEMPERATURE OF PREPARATION $1100^{\circ} \mathrm{C}$; HYDROGEN CONTENT 0.28 PERCENT

\begin{tabular}{|c|c|c|c|c|c|c|c|c|c|c|c|c|c|c|c|}
\hline $\begin{array}{l}76-63 \\
76-65 \\
76-67 \\
76-55-57 \\
76-59-10 \\
76-35 \\
76-41 \\
76-47-49\end{array}$ & 162 & $\begin{array}{c}5.74 \\
7.91 \\
13.32 \\
23.08\end{array}$ & $\begin{array}{l}25.8 \\
30.5 \\
60.9 \\
89.0\end{array}$ & $\begin{array}{r}0.222 \\
.259 \\
.219 \\
.259\end{array}$ & $\left\{\begin{array}{l}0.99067 \\
.98305 \\
.97697 \\
1.00103 \\
0.97008 \\
.99144 \\
1.00280 \\
0.9885 \\
.95612 \\
1.01157\end{array}\right.$ & $\begin{array}{l}\text { 3. } 35316 \\
\text { 3. } 32082 \\
\text { 3. } 30689 \\
\text { 3. } 35301 \\
\text { 3. } 30821 \\
\text { 3. } 32083 \\
\text { 3. } 33345 \\
\text { 3. } 29032 \\
\text { 3. } 14044 \\
\text { 3. } 33037\end{array}$ & $\begin{array}{l}0.22332 \\
.22161 \\
.22103 \\
.22281 \\
.22040 \\
.22049 \\
.22285 \\
.21944 \\
.20949 \\
.22127\end{array}$ & $\begin{array}{l}2868.85 \\
286.35 \\
2866.35 \\
2884.60 \\
2887.00 \\
2878.40 \\
2874.20 \\
2876.60 \\
2877.35 \\
2888.95\end{array}$ & $\begin{array}{r}-312.9 \\
-406.2 \\
-422.9 \\
+424.2 \\
+446.4 \\
+101.7 \\
-36.8 \\
+89.1 \\
+143.5 \\
+995.3\end{array}$ & $\begin{array}{l}138,730 \\
138,637 \\
138,620 \\
139,467 \\
139,489 \\
139,145 \\
139,006 \\
139,132 \\
139,187 \\
140,038\end{array}$ & $\begin{array}{r}10.1 \\
8.6 \\
10.4 \\
7.9 \\
0.3 \\
9.1 \\
12.4 \\
7.8 \\
6.4 \\
11.2\end{array}$ & $\begin{array}{r}8.9 \\
16.4 \\
68.3 \\
66.8 \\
111.3 \\
18.6 \\
53.5 \\
12.6 \\
58.6 \\
77.3\end{array}$ & $\begin{array}{l}33,837 \\
33,874 \\
33,865 \\
33,879 \\
33,930 \\
33,824 \\
33,981 \\
33,980 \\
33,947 \\
33,899\end{array}$ & $\left\{\begin{array}{l}33,859 \\
33,878 \\
33,980 \\
33,923\end{array}\right.$ & $\begin{array}{l}8093.8 \\
8098.4 \\
8122.8 \\
8109.1\end{array}$ \\
\hline Group average... & & 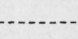 & $=$ & & & & & & & & & & & $33,902 \pm 32$ & $8104.1 \pm 7.8$ \\
\hline \multicolumn{16}{|c|}{ TEMPERATURE OF PREPARATION $1,150^{\circ} \mathrm{C}$; HYDROGEN CONTENT 0.21 PEROENT } \\
\hline 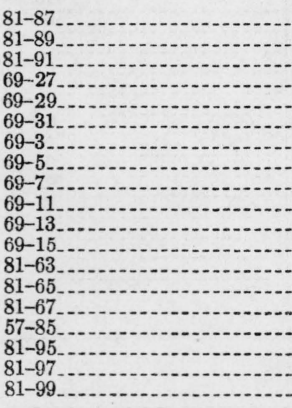 & 106 & $\begin{array}{l}4.19 \\
6.04\end{array}$ & 66.2 & $\begin{array}{l}.255 \\
.091\end{array}$ & $\left\{\begin{array}{l}1.00056 \\
0.96062 \\
.96111 \\
.96010 \\
.96146 \\
.96221 \\
.96655 \\
.96175 \\
.96187 \\
.96206 \\
.96534 \\
.95984 \\
.94779 \\
.94783 \\
.94782 \\
.96549 \\
.95995 \\
.96053 \\
.95989\end{array}\right.$ & $\begin{array}{l}\text { 3. } 45744 \\
\text { 3. } 30745 \\
\text { 3, } 31591 \\
\text { 3. } 31507 \\
\text { 3. } 30886 \\
\text { 3. } 32218 \\
\text { 3. } 32280 \\
\text { 3. } 30499 \\
\text { 3. } 29501 \\
\text { 3. } 29350 \\
\text { 3. } 30808 \\
\text { 3. } 28528 \\
\text { 3. } 21941 \\
\text { 3. } 25374 \\
\text { 3. } 25666 \\
\text { 3. } 30311 \\
\text { 3. } 28587 \\
\text { 3. } 29269\end{array}$ & $\begin{array}{l}0.22970 \\
.21950 \\
.21870 \\
.21999 \\
.21998 \\
.22072 \\
.22149 \\
.21991 \\
.21992 \\
.21934 \\
.22050 \\
.22053 \\
.21385 \\
.21602 \\
.21659 \\
.21959 \\
.21910 \\
.21823 \\
.21925\end{array}$ & $\begin{array}{l}2878.20 \\
2874.30 \\
2896.55 \\
2875.00 \\
2867.30 \\
2874.80 \\
2870.60 \\
2875.35 \\
2866.75 \\
2871.90 \\
2888.35 \\
2847.50 \\
2877.30 \\
2881.35 \\
2878.55 \\
2875.25 \\
2866.05 \\
2873.74 \\
2882.90\end{array}$ & $\begin{array}{r}+87.0 \\
-73.2 \\
+849.6 \\
+37.6 \\
-334.2 \\
-17.6 \\
-194.9 \\
+4.6 \\
-357.7 \\
-142.2 \\
-290.7 \\
-1,166.7 \\
+38.9 \\
+220.9 \\
+99.1 \\
+29.3 \\
-419.6 \\
-102.9 \\
+275.3\end{array}$ & $\begin{array}{l}139,130 \\
138,970 \\
139,893 \\
139,081 \\
138,709 \\
139,025 \\
138,848 \\
139,048 \\
138,685 \\
138,091 \\
138,752 \\
137,876 \\
139,082 \\
139,264 \\
139,142 \\
139,072 \\
138,623 \\
138,940 \\
139,318\end{array}$ & $\begin{array}{r}4.3 \\
8.3 \\
6.1 \\
12.9 \\
14.6 \\
8.5 \\
13.2 \\
10.0 \\
12.5 \\
11.5 \\
14.4 \\
10.8 \\
6.6 \\
10.0 \\
15.4 \\
11.9 \\
8.6 \\
5.9 \\
12.3\end{array}$ & $\begin{array}{r}78.0 \\
8.2 \\
7.4 \\
43.8 \\
14.4 \\
69.8 \\
86.2 \\
81.6 \\
75.8 \\
83.2 \\
84.5 \\
102.8 \\
27.5 \\
8.2 \\
17.8 \\
13.4 \\
21.5 \\
6.6 \\
155.9\end{array}$ & $\begin{array}{l}33,784 \\
33,778 \\
33,795 \\
33,758 \\
33,760 \\
33,761 \\
33,806 \\
33,802 \\
33,821 \\
33,792 \\
33,784 \\
33,788 \\
33,815 \\
33,861 \\
33,873 \\
33,847 \\
33,838 \\
33,852 \\
33,791\end{array}$ & $\left\{\begin{array}{l}33,785 \\
33,760 \\
33,810 \\
33,788 \\
33,850\end{array}\right.$ & $\begin{array}{l}8076.2 \\
8070.2 \\
8082.1 \\
8076.9 \\
8091.7\end{array}$ \\
\hline Group average........... & & & & & & & & & & & & & & $33,806 \pm 16$ & $8081.2 \pm 3.9$ \\
\hline
\end{tabular}

1 The amount of reaction was determined from the mass of carbon dioxide formed. $44.010 / 12.010 \mathrm{~g}$ of carbon dioxide was taken as equivalent to $1 \mathrm{~g}$ of carbon.

3 The error given is equal to three times the probable error of the mean. 
TABLE 4.-Heats of combustion of anthracite cokes-Continued

[Average mean temperature, $24.80^{\circ} \mathrm{C}$ ]

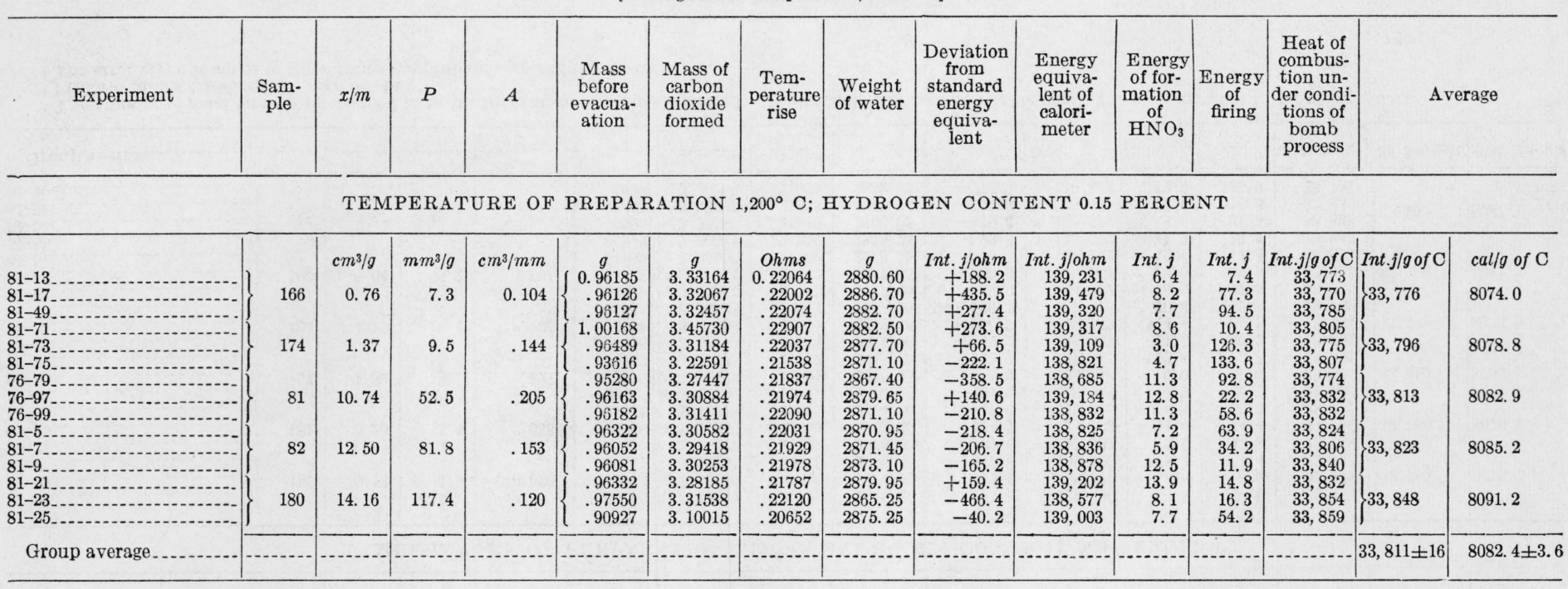


TEMPERATURE OF PREPARATION $1,300^{\circ} \mathrm{C}$; HYDROGEN CONTENT 0.08 PERCENT

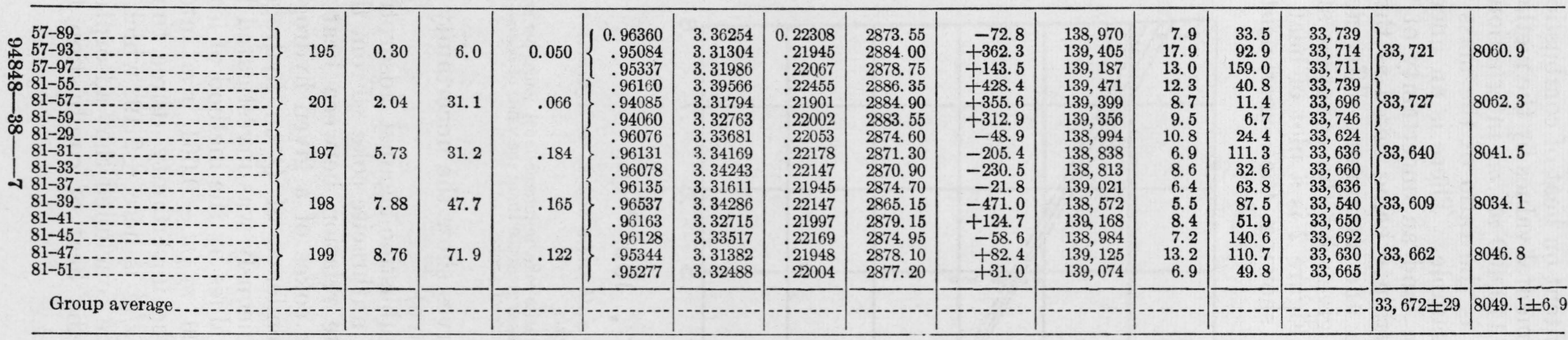


To determine the effect of hydrogen content on heat of combustion, $Q$, a linear relation was fitted to the experimental values by the method of least squares. This gave $Q=33,590+110,400 \mathrm{~m}_{\mathrm{H}} / \mathrm{m}_{\mathrm{c}}$ international joules per gram of carbon, where $m_{\mathrm{H}} / m_{\mathrm{c}}$ is the ratio of the mass of hydrogen to the mass of carbon in the sample. There is an uncertainty of 6,000 in the coefficient of $m_{\mathrm{H}} / m_{\mathrm{c}}$ and an uncertainty of 23 in the value of $Q$ at $m_{\mathrm{H}} / m_{\mathrm{c}}=0$, the uncertainty being taken as three times the probable error. The average and maximum differences between the observed values and those given by the equation are, respectively, 44 and $148 \mathrm{j} / \mathrm{g}$ of carbon. Figure 2 is a plot of heat of combustion against hydrogen content, showing the experimental

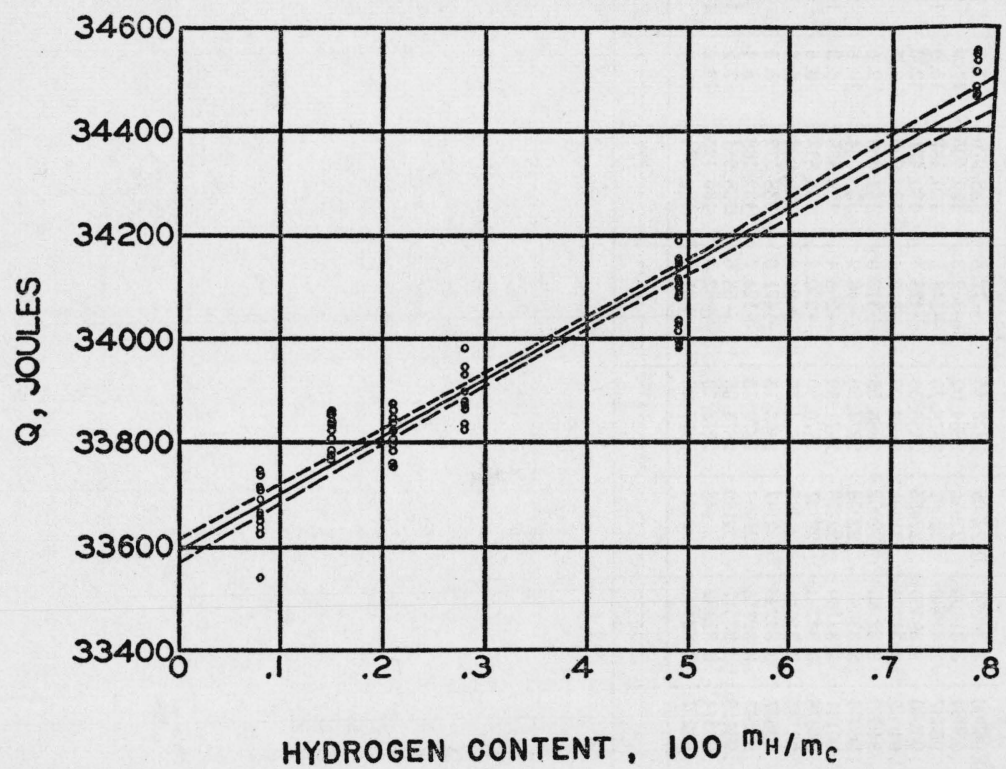

FIGURE 2.-Plot of the heat of combustion of the anthracite coles, as a function of the hydrogen content.

The scale of ordinates gives the heat of combustion of the anthracite coke, in international joules per gram of carbon, for the bomb process at $25^{\circ} \mathrm{C}$. The scale of abscissas gives 100 times the value of $m_{\mathrm{B}} / m_{\mathrm{c}}$, the ratio of the mass of hydrogen to the mass of carbon in the anthracite coke.

values and the fitted line; the dashed curves show the uncertainty in the position of the line (calculated as above).

Figure 3 is a plot of the heat of combustion against adsorptive capacity, $x / m$, for the various samples of anthracite coke. From this plot it appears that there is no definite relation between heat of combustion and adsorptive capacity, for cokes of a given hydrogen content. To test this result, the dependence of $Q$ on hydrogen content and adsorptive capacity simultaneously was investigated by fitting a linear relation to the observed values by the method of least squares. This gave $Q=33,591+110,600 \quad m_{\mathrm{H}} / m_{\mathrm{c}}-0.061 \mathrm{x} / \mathrm{m}$ international joules per gram of carbon. The uncertainty (three times the probable error) in the coefficient of $x / m$ is here \pm 2.19 , which is 36 times its own value. Hence it may be concluded that adsorptive capacity has relatively little effect on the heat of combustion for 
given values of hydrogen content, and that the effect of adsorptive capacity may be neglected in comparison with errors arising from impurities or other causes. The same appears to be true for porosity, $P$, and activity, $A$.

In view of this fact, it may be stated that, within the limits of uncertainty of the data, the heats of combustion of these samples of anthracite cokes are dependent only on hydrogen content, as given by the previously stated relation, $Q=(33,590 \pm 23)+(110,400 \pm 6000)$ $m_{\mathrm{H}} / m_{\mathrm{c}}$ international joules per gram of carbon. It may be pointed out that the coefficient of $m_{\mathrm{H}} / m_{\mathrm{c}}$ is considerably less than the 140,000 int. $\mathrm{j}(33,500 \mathrm{cal})$ per gram of hydrogen, which would be obtained if the heat of combustion of the hydrogen in the cokes were equal to

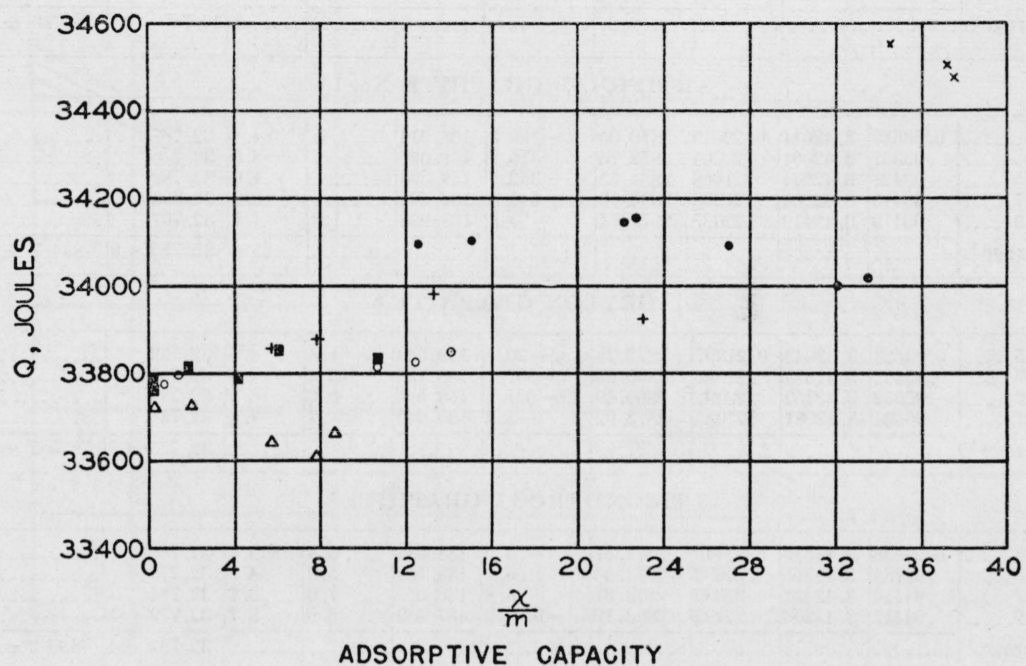

FIGURE 3.-Plot of the heat of combustion of the anthracite cokes, of various given hydrogen contents, as a function of the adsorptive capacity.

The scale of ordinates gives the heat of combustion of the anthracite coke, in international joules per gram of carbon, for the bomb process at $25^{\circ} \mathrm{C}$. The scale of abscissas gives the value of the adsorptive capacity, $x / m$, which is the volume in milliliters of carbon dioxide adsorbed per gram of carbon at $0^{\circ} \mathrm{C}$ and a pressure of $760 \mathrm{~mm} \mathrm{Hg}$. The symbols indicate the following temperatures of preparation and hydrogen contents, respectively: $\times, 900^{\circ} \mathrm{C}, 0.78$ percent of $\mathrm{H} ; 8,1,000^{\circ} \mathrm{C}, 0.49$ percent of $\mathrm{H} ;+, 1,100^{\circ} \mathrm{C}, 0.28$ percent of $\mathrm{H} ; 1,150^{\circ} \mathrm{C}, 0.21$ percent of $\mathrm{H} ; \mathrm{O}, 1,200^{\circ} \mathrm{C}, 0.15$ percent of $\mathrm{H} ; \Delta, 1,300^{\circ} \mathrm{C}, 0.08$ percent of $\mathrm{H}$

the heat of combustion of gaseous hydrogen. The significance of this difference probably lies partly in the fact that the experimentally determined coefficient includes contributions of other physical or chemical properties of the cokes which may affect their heats of combustion.

\section{ARTIFICIAL AND NATURAL GRAPHITES}

For comparison with the heat of combustion of carbon in the anthracite cokes obtained by extrapolation to zero hydrogen content, similar calorimetric data were obtained for two samples of artificial graphite and for four samples of natural graphite. The data are given in table 5, and descriptions of the different graphites are given in the footnotes of the table. 


\section{TABLE 5.-Heats of combustion of artificial and natural graphites}

[A verage mean temperature $=24.8^{\circ} \mathrm{C}$.]

ARTIFICIAL GRAPHITE No. $0^{1}$

\begin{tabular}{|c|c|c|c|c|c|c|c|c|c|c|}
\hline $\begin{array}{l}\text { Experi- } \\
\text { ment }\end{array}$ & $\begin{array}{c}\text { Mass of } \\
\text { sample } \\
\text { before } \\
\text { evacua- } \\
\text { tion }\end{array}$ & $\begin{array}{l}\text { Mass of } \\
\text { carbon } \\
\text { dioxide } \\
\text { formed }\end{array}$ & $\begin{array}{l}\text { Tem- } \\
\text { pera- } \\
\text { ture } \\
\text { rise }\end{array}$ & $\begin{array}{l}\text { Weight } \\
\text { of } \\
\text { water }\end{array}$ & $\begin{array}{l}\text { Correc- } \\
\text { tion from } \\
\text { "stand- } \\
\text { ard"ener- } \\
\text { gy equiv- }\end{array}$ & $\begin{array}{l}\text { Energy } \\
\text { equiva- } \\
\text { lent of } \\
\text { calori- } \\
\text { meter }\end{array}$ & $\begin{array}{c}\text { Energy } \\
\text { of for- } \\
\text { mation } \\
\text { of nitric } \\
\text { acid }\end{array}$ & $\begin{array}{l}\text { Ener- } \\
\text { gy of } \\
\text { firing }\end{array}$ & \multicolumn{2}{|c|}{$\begin{array}{l}\text { Heat of combustion } \\
\text { under conditions of the } \\
\text { bomb process, per gram } \\
\text { of carbon burned } 6\end{array}$} \\
\hline $\begin{array}{l}76-71 \ldots \\
76-73 \ldots \\
76-93 \\
76-95 \ldots\end{array}$ & $\begin{array}{c}g \\
0.93516 \\
.93462 \\
.93566 \\
.93398 \\
\end{array}$ & $\begin{array}{c}g \\
\text { 3. } 42670 \\
\text { 3. } 42340 \\
\text { 3. } 42713 \\
\text { 3. } 42157\end{array}$ & $\begin{array}{l}\text { Ohms } \\
0.22139 \\
.21933 \\
.22060 \\
.22057\end{array}$ & $\begin{array}{c}g \\
2859.37 \\
2888.72 \\
2873.64 \\
2867.23\end{array}$ & $\begin{array}{r}j / 0 h m \\
-586.1 \\
654.7 \\
20.5 \\
-248.1 \\
\end{array}$ & $\begin{array}{c}\text { Int. } \\
\text { j/ohm } \\
138,457 \\
139,698 \\
139,063 \\
138,795\end{array}$ & \begin{tabular}{r}
$j_{0.8}$ \\
.3 \\
\hdashline- \\
\end{tabular} & $\begin{array}{l}j \\
4.4 \\
3.7 \\
3.7 \\
4.4\end{array}$ & $\begin{array}{l}\text { Int. }{ }^{j} \\
32,774 \\
32,793 \\
32,798 \\
32,782\end{array}$ & $\begin{array}{c}\text { cal } \\
\end{array}$ \\
\hline Average? & $\ldots$ & & .... & - & $-\cdots$ & $\ldots$ & -- & - & $32,787 \pm 11$ & $7837.6 \pm 2.6$ \\
\hline
\end{tabular}

ARTIFICIAL GRAPHITE No. 11

\begin{tabular}{|c|c|c|c|c|c|c|c|c|c|c|}
\hline $\begin{array}{l}7-5 \\
7-9 \\
7-15 \\
7-19\end{array}$ & $\begin{array}{r}0.93339 \\
.93367 \\
.93427 \\
.93413 \\
.93419 \\
\end{array}$ & & $\begin{array}{r}0.22019 \\
.22004 \\
.21968 \\
.21938 \\
.22035\end{array}$ & & $\begin{array}{r}-129.3 \\
-15.9 \\
352.7 \\
548.8 \\
-59.8\end{array}$ & & 1. 3 & $\begin{array}{l}4.4 \\
3.0 \\
4.9 \\
3.0 \\
4.5\end{array}$ & & 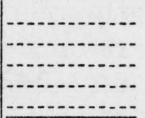 \\
\hline & & & & & & & & & $\overline{32,775 \pm 9}$ & $7834.7 \pm 2$ \\
\hline
\end{tabular}

CEYLON GRAPHITE 2

\begin{tabular}{|c|c|c|c|c|c|c|c|c|c|c|}
\hline $\begin{array}{l}87-25 \\
87-27 \ldots \\
87-29 \\
87-31\end{array}$ & $\begin{array}{r}0.93523 \\
.95862 \\
.96252 \\
.96134 \\
\end{array}$ & $\begin{array}{l}3.32943 \\
3.41393 \\
3.42452 \\
3.42081 \\
\end{array}$ & $\begin{array}{r}0.21397 \\
.21988 \\
.22092 \\
.21985 \\
\end{array}$ & $\begin{array}{l}2872.78 \\
2865.83 \\
2860.59 \\
2873.02 \\
\end{array}$ & $\begin{array}{r}-20.5 \\
-307.1 \\
-527.5 \\
-3.3 \\
\end{array}$ & $\begin{array}{l}139,023 \\
138,736 \\
138,515 \\
139,040\end{array}$ & \begin{tabular}{r|}
1.4 \\
3.4 \\
0.2 \\
.7 \\
\end{tabular} & $\begin{array}{l}4.5 \\
4.9 \\
6.2 \\
7.4\end{array}$ & $\begin{array}{l}32,733 \\
32,735 \\
32,738 \\
32,736 \\
\end{array}$ & - \\
\hline Average ${ }^{8}$ & & & & & & & $\ldots$ & $\ldots$ & $32,735 \pm 2$ & $7825.2 \pm 0.5$ \\
\hline
\end{tabular}

TICONDEROGA GRAPHITE 3

\begin{tabular}{|c|c|c|c|c|c|c|c|c|c|c|}
\hline $\begin{array}{l}87-43 \\
87-45 \\
87-47 \\
87-49\end{array}$ & $\begin{array}{r}0.95638 \\
.93784 \\
.94116 \\
.94117\end{array}$ & $\begin{array}{l}3.48515 \\
3.40365 \\
3.42431 \\
3.42200\end{array}$ & $\begin{array}{r}0.22440 \\
.21892 \\
.22039 \\
.22292 \\
\end{array}$ & \begin{tabular}{l|}
2871.77 \\
2874.56 \\
2873.31 \\
2833.12
\end{tabular} & $\begin{array}{r}-59.0 \\
60.2 \\
8.8 \\
-1684.2\end{array}$ & $\begin{array}{l}138,984 \\
139,103 \\
139,052 \\
137,359\end{array}$ & $\begin{array}{l}3.4 \\
5.0 \\
7.0 \\
5.9\end{array}$ & $\begin{array}{l}3.7 \\
4.9 \\
3.4 \\
3.7 \\
\end{array}$ & $\begin{array}{l}32,785 \\
32,776 \\
32,784 \\
32,779 \\
\end{array}$ & - \\
\hline A verage. & & - & & & & & $\ldots$ & $\ldots$ & $32,781 \pm 4$ & $7836.2 \pm 1.0$ \\
\hline
\end{tabular}

\section{BUCKINGHAM GRAPHITE *}

\begin{tabular}{|c|c|c|c|c|c|c|c|c|c|c|}
\hline $\begin{array}{l}87-53 \ldots \ldots \\
87-55 \ldots \ldots \\
87-57 \ldots \ldots \\
87-59\end{array}$ & $\begin{array}{r}0.93532 \\
.94171 \\
.94167 \\
.94060 \\
\end{array}$ & $\begin{array}{l}\text { 3. } 40147 \\
3.42359 \\
3.42113 \\
\text { 3. } 41774 \\
\end{array}$ & $\begin{array}{r}0.21888 \\
.22047 \\
.22022 \\
.21999 \\
\end{array}$ & $\begin{array}{l}2873.75 \\
2871.79 \\
2873.39 \\
2871.94 \\
\end{array}$ & $\begin{array}{r}25.9 \\
-55.6 \\
10.5 \\
-49.8 \\
\end{array}$ & $\begin{array}{l}139,069 \\
138,987 \\
139,053 \\
138,993\end{array}$ & $\begin{array}{l}4.8 \\
6.1 \\
5.1 \\
5.4\end{array}$ & $\begin{array}{l}4.4 \\
4.4 \\
4.4 \\
5.2 \\
\end{array}$ & $\begin{array}{l}32,784 \\
32,790 \\
32,790 \\
32,773 \\
\end{array}$ & - \\
\hline A verage.. & $\ldots$ & $\ldots$ & 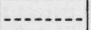 & - & $\ldots$ & - & $\ldots-$ & $\ldots$ & $32,784 \pm 8$ & $7836.8 \pm 1.9$ \\
\hline
\end{tabular}

BAFFIN ISLAND GRAPHITE 5

\begin{tabular}{|c|c|c|c|c|c|c|c|c|c|c|}
\hline $\begin{array}{l}87-33 \ldots \ldots \\
87-35 \ldots \\
87-37 \ldots \ldots \\
87-39\end{array}$ & $\begin{array}{r}0.96171 \\
.96106 \\
.95593 \\
.94868 \\
\end{array}$ & $\begin{array}{l}\text { 3. } 44619 \\
3.44440 \\
3.42705 \\
3.40527\end{array}$ & $\begin{array}{r}0.22196 \\
.22171 \\
.22056 \\
.21910 \\
\end{array}$ & $\begin{array}{l}2870.61 \\
2872.91 \\
2874.75 \\
2871.85 \\
\end{array}$ & $\begin{array}{r}-105.4 \\
-7.9 \\
67.4 \\
-55.6 \\
\end{array}$ & $\begin{array}{l}138,938 \\
139,035 \\
139,110 \\
138,987\end{array}$ & $\begin{array}{r}4.4 \\
2.1 \\
4.4\end{array}$ & $\begin{array}{r}4.4 \\
2.1 \\
-4.4\end{array}$ & $\begin{array}{l}32,784 \\
32,789 \\
32,807 \\
32,760 \\
\end{array}$ & - \\
\hline Average. & $-\ldots \ldots$ & $\ldots \ldots$ & $\bar{\ldots} \ldots$ & & $\ldots$ & $\ldots$ & & & $32,785 \pm 20$ & $\overline{7836.8 \pm 4.7}$ \\
\hline
\end{tabular}

1 Two samples of spectroscopic-grade graphite from the National Carbon Co. reported to contain only 5 parts per million of impurities.

${ }^{2}$ Sample was approximately a 50-g lump, very uniform, and definitely, although irregularly, crystalline. Contained 2.2 percent of ash. Material passing 150-mesh contained 2.3 percent of ash; material not passing 150 -mesh contained 2.2 percent of ash.

3 Sample was approximately a 100-g lump, uniform and definitely crystalline. Ash = 0.33 percent. Material passing 150 -mesh contained 0.38 percent of ash; material not passing 150 -mesh contained 0.30 percent of ash.

1 Sample was an approximately $1-\mathrm{kg}$ lump of very definite columnar structure, the crystals being about 1.5 to $2 \mathrm{~cm}$ long in three distinet layers. The crystals were flat and needle-like. Material passing 150 -mesh contained 0.25 percent of ash; material not passing 150 -mesh contained 0.11 percent of ash.

${ }^{5}$ Sample was an approximately 250 -g lump consisting of very well defined crystals. Ash $=4.1$ percent. Material passing 150-mesh contained 1.7 percent of ash; material not passing 150 -mesh contained 0.44 percent of ash.

${ }^{6}$ The amount of reaction was determined from the mass of carbon dioxide formed. $44.010 / 12.010 \mathrm{~g}$ of carbon dioxide was taken as equivalent to $1 \mathrm{~g}$ of carbon.

7 The average for the two samples of artificial graphite is $32,780 \pm 8 \mathrm{int}$. j, or $7835.9 \pm 1.9 \mathrm{cal} / \mathrm{g}$ of carbon.

8 See p. 482 of the RP 1140 regarding this low value for Ceylon graphite. 
After grinding and sifting, that material which passed through 150 -mesh platinum wire gauze was used for the measurements. It is to be noted that the heats of combustion per gram of carbon for the artificial, Ticonderoga, Buckingham, and Baffin Island graphites are, respectively, $32,780,32,781,32,784$, and 32,785 int. $\mathrm{j}$, and on the average differ by about 2.4 percent from the value 33,590 int. $j$ obtained for the heat of combustion per gram of carbon in the anthracite cokes. The low value for Ceylon graphite is explained in the following paper (p. 482).

These values are in terms of the bomb process, which is a constantvolume process at an initial pressure of 30 atmospheres. In order to reduce these to $-\Delta U_{R}$, the heat of reaction under standard conditions for the pure reaction

$$
\mathrm{C}_{(\mathrm{s}, 1 \mathrm{~atm})}+\mathrm{O}_{2(\mathrm{~g}, 1 \mathrm{~atm})} \longrightarrow \mathrm{CO}_{2(\mathrm{~g}, 1 \mathrm{~atm})},
$$

the reaction taking place without the production of external work, the reduction eq 81 of Washburn [12] is used. This Washburn reduction amounts to $-0.379 \mathrm{int} . \mathrm{kj} / \mathrm{mole}$ for pure carbon under the conditions of this work. Using this correction, the values of $-\Delta U_{R}$, the heat of the reaction in international kilojoules of 1 mole of carbon under standard conditions at $25^{\circ} \mathrm{C}$, are as follows: Artificial graphite No. $0,393.39 \pm 0.17$; artificial graphite No. $1,393.25 \pm 0.15$; Ticonderoga natural graphite, $393.32 \pm 0.11$; Buckingham natural graphite, 393.35 \pm 0.13 ; Baffin Island natural graphite, $393.37 \pm 0.26$; hydrogen-free anthracite coke, $403.03 \pm 0.29$ (obtained by linear extrapolation to zero hydrogen content of the data on hydrogen-containing cokes).

The percentage uncertainty assigned to these final values is the total uncertainty defined as $\pm \sqrt{a^{2}+b^{2}+c^{2}}$ percent, where $a$ is the percentage error assigned by Jessup and Green [12] for the value of the heat evolved when $1 \mathrm{~g}$ of benzoic acid is burned in the bomb $(0.023 \%) ; b$ is the uncertainty in the energy equivalent of the calorimeter as given in table $2(0.009 \%)$; and $c$ is the uncertainty assigned to the final combustion experiments on the given sample of carbon, taken as three times the probable error of the mean and expressed in percent.

The authors acknowledge their indebtedness to the Bell Telephone Laboratories for the anthracite cokes and the physical and chemical data relating to them; to F. D. Rossini and R. S. Jessup of the National Bureau of Standards for their valuable suggestions and aid in the preparation of the manuscript; to $\mathrm{H}$. G. Landau, who made most of the calculations; and to H. H. Lowry, Director of the Coal Research Laboratory, under whose direction this work was carried out. 


\section{REFERENCES}

[1] Mixter, Am. J. Sci. [4] 19, 434 (1905).

[2] Roth and Wallasch, Ber. deut. chem. Ges. 46, 896 (1913).

[3] Roth and Wallasch, Z. Elektrochem. 21, 1 (1915).

[4] Roth and Doepke, Ber. deut. chem. Ges. 50, 530 (1927).

[5] Roth and Naeser, Z. Elektrochem. 31, 461 (1925).

6] Roth, Arch. Eisenhüttenw. 2, 245 (1928).

[7] Plummer, Ind. Eng. Chem. 22, 630 (1930).

[8] Berthelot and Petit, Compt. rend. 108, 1144 (1889).

[9] Lowry, J. Phys. Chem. 33, 1332 (1929).

[10] Dickinson, BS Sci. Pap. 11, 210 and 219 (1914) S230.

[11] Rossini, BS J. Research 6, 37 (1931) RP260.

[12] Washburn, BS J. Research 10, 525 (1933) RP546; Jessup and Green, 13, 469 (1934) RP721.

[13] Lowry, J. Phys. Chem. 34, 63 (1930).

[14] Rossini, Chem. Rev. 18, 233 (1936).

Pittsburgh, December 22, 1937. 